delivered DNA by quantifying mRNA. As a result, transcription efficiency (Etranscript) of LFN was about 16 times less than that for adenovirus. Furthermore, translation efficiency (Etranslate) was approximately 460 times less in LFN. Collectively, an improvement in nuclear decondensation and reduction of interaction between vector and mRNA is essential to establish a new generation of non-viral vectors.

\section{SA2-10 プリオン病一感染メカニズムとダイナミクスに基づく創薬}

Prion diseases - Biophysical approach to the infection mechanism and the structure based drug design -

Kazuo Kuwata (1) ((1) Center for Emerging Infectious Diseases,Gifu University)

Conformational conversion of the normal form of prion protein $\left(\operatorname{PrP}^{\mathrm{C}}\right)$ to a scrapie form $\left(\mathrm{PrP}^{\mathrm{Sc}}\right)$ plays a central role in the pathogenesis of prion diseases. However, the infection mechanism of prion has been still unclear. Although some synthetic compounds which can interfere with the $\mathrm{PrP}^{\mathrm{Sc}}$ production have been discovered, their inhibitory mechanisms still remain unknown. Objectives of the research is to elucidate the infectious mechanism of prion and the inhibitory mechanism of antiprion compounds, based on the structural dynamical information on prion protein, i.e. characteristics of an intermediate state $\operatorname{PrP}^{*}$, and further to optimise the chemical structures of compounds. Initially to identify the $\operatorname{PrP}^{*}$ specific sites, the chemical shift alterations under various $\operatorname{PrP}^{S c}$ producing conditions have been observed using various NMR methods. For the rational design of molecules targeting these sites, we have developed a unique software, 'NAGARA', in which from quantum (fragment MO) to classical simulations (all atom \& coarse grained dynamics) are included.

$\mathrm{PrP}^{*}$ specific sites are existent from the C-terminal region of the helix $\mathrm{B}$ to the central region of helix $\mathrm{C}$. Based on the simulated results, we have synthesized a series of compounds with strong anti-prion activities, and identified the essential scaffolds necessary for the activity. Intriguingly, the amplitudes of chemical shift perturbations upon binding with these anti-prion compounds dramatically increased upon decrease of $\mathrm{IC}_{50}$ of compounds, indicating the local stability of the prion-ligand interaction sites is crucial for their inhibitory action. Application of these findings may well lead to the way for the development of therapeutics for prion diseases.

1SA3-01インフルエンザウイルスの RNA ポリメラーゼにおけるサブユニ ット間相互作用

Structural insight into essential subunit contacts of the influenza virus RNA polymerase

Eiji Obayashi (1), Kanako Sugiyama (1), Hisashi Yoshida (1), Fumihiro Kawai (1), Atsushi Kawaguchi (2), Yukari Suzuki (2), Jeremy Tame (1), Kyosuke Nagata (2), Sam-Yong Park (1) ((1) Protein Design Laboratory, Yokohama City University: (2) Grad. Sch. of Comprehensive Human Sci., Univ. of Tsukuba)

The recent outbreak of a new, swine-related $\mathrm{H} 1 \mathrm{~N} 1$ influenza virus in Mexico has affected the entire world economy, even though it is not as pathogenic as imagined at first. Standard medication, such as NA inhibitors Tamiflu and Relenza, have proved effective against this virul strain, but present vaccines are not. This current pandemic shows that there is still danger of the emergence of new type influenza viruses. New viral strains against which humans have no immunity are spread rapidly from person to person. Furthermore, the swinerelated $\mathrm{H} 1 \mathrm{~N} 1$ influenza virus is a hybrid of human, swine and highly pathogenic avian strains. This means that it is only a matter of time before a new highly pathogenic and Tamiflu-resistant influenza virus emerges, and we have to prepare for it.

The viral RNA-polymerase is not yet a target of any approved pharmaceutical, but has recently become a focus for the development of new anti-influenza drugs since it is highly conserved in avian and human influenza. It carries out a number of essential processes in the viral life cycle, many of which remain poorly understood. The three subunits, PB1, PB2 and PA play different roles within the polymerase, and are all essential for viral replication, but despite considerable functional analysis relatively little is known about their structure. PA and PB2 both bind PB1, but not each other. Here, we have solved crystal structures of the two subunit interaction surfaces, PA-PB1 and PB2-PB1. We have found highly conserved residues which are essential for these interactions, and demonstrated that the interruption of these interfaces dramatically reduces viral replication. These interfaces have considerable potential as a drug target sites, which are entirely independent of surface antigen type.

1SA3-02 インフルエンザ RNA ポリメラーゼ PB2 サブユニット病原性関与 ドメインの構造と機能の解析

Structural basis of the influenza A virus RNA polymerase PB2 RNA-binding domain containing the pathogenicity-determinant lysine 627 residue

Takashi Kuzuhara (1), Hideaki Tsuge (1), Hiroko Utsunomiya (1), Noriko Echigo (1), Daisuke Kise (1) ((I) Tokushima Bunri University)

Since the influenza A virus has an RNA genome, its RNA-dependent RNA polymerase, comprising three subunits, the PA, PB1 and PB2 subunits, is essential for viral transcription and replication. The binding of RNA primers/promoters to the polymerases is an initiation step in viral transcription. In our current study, we reveal the $2.7 \AA$ tertiary structure of the C-terminal RNAbinding domain of $\mathrm{PB} 2$ by X-ray crystallography. This domain incorporates lysine 627 of PB2, and this residue is associated with the high pathogenicity and host range restriction of influenza A virus. We found from our current analyses that this lysine is located in a unique " $\Phi$ "-shaped structure consisting of a helix and an encircled loop within the PB2 domain. By electrostatic analysis we identified a highly basic groove along with this loop and found that lysine 627 is located in the loop. A PB2 domain mutant in which glutamic acid is substituted at position 627 shows significantly lower RNA-binding activity. This is the first report to show a relationship between RNA-binding activity and the pathogenicity-determinant lysine 627 . Using the Matras program for protein $3 \mathrm{D}$ structure structural comparisons, we further found that the helix bundles in the PB2 domain are similar to that of activator 1 , the $40 \mathrm{kDa}$ subunit of DNA replication clamp loader (replication factor $\mathrm{C}$ ), which is also an RNA-binding protein. This suggests a functional and structural relationship between the RNAbinding mechanisms in underlying both influenza $\mathrm{A}$ viral transcription and cellular DNA replication. Our present results thus provide important new information for developing novel drugs that target the primer/promoter RNAbinding of viral RNA polymerases.

\section{SA3-03＼cjkstart光ピンセットを用いたインフルエンザウイルス感染による細胞変 化の解析}

Analysis of the changing of cell by influenza virus infection using the optical tweezers

Ayae Honda (1) ((1) Housei University)

Influenza virus RNA dependent-RNA polymerase is composed of three proteins, PB2, PB1 and PA. The genome of influenza virus was negative sense RNA. This polymerase functions both transcriptase and replicase. It is required the capped RNA as a primer for transcriptase activity, while when the RNA polymerase functions as replicase, RNA synthesis initiates primer independently. Using the purified RNA polymerase that formed different complexes, PB2-PB1-PA, PB2PB1 and PB1-PA, it was found that both PB2-PB1-PA and PB1-PB2 functioned as transcriptase, while $\mathrm{PB} 1-\mathrm{PA}$ complex functioned as replicase. We expected host protein(s) involved in the conversion of influenza virus RNA dependent RNA polymerase from transcriptase to replicase. To identify the host protein(s) we attempted to screen the host protein using yeast two-hybrid screening system. We identified nine candidates. Ebp1 was interacted with PB1 subunit at Cterminal region. Ebp1 was also interacted with several proteins, ErbB3, P53, Rb, HDAC at C-terminal region (reported by Humberger's group). Ebp1 inhibited in vitro RNA synthesis, but not endonuclease and cap binding activity of influenza virus RNA polymerase. Ebp1 did not inhibit the reverse transcriptase activity of AMV. The assay using Ebp1 over-expression plasmid and siRNA indicated that Ebp1 inhibited the virus multiplication. Interestingly western blotting assay for Ebp1 indicated that Ebp1 expression induced by influenza virus infection. I would like to discuss the inhibitory mechanism of Ebpl on influenza virus RNA polymerase.

\section{SA3-04インフルエンザウイルス RNA ゲノムータンパク質複合体輸送の 生細胞観察}

Live cell imaging of the trafficking of influenza viral ribonucleoprotein complexes

Fumitaka Momose (1) ((1) Kitasato Institute for Life Sciences, Kitasato Univ.)

An individual segment of the influenza virus RNA genome forms ribonucleoprotein complex ( $\mathrm{VRNP}$ ) with viral RNA polymerase and nucleoprotein (NP), and is replicated in the nucleus. At the late phase of infection, progeny vRNPs are exported to the cytoplasm, and finally a set of $8 \mathrm{vRNP}$ segments is incorporated into a virion, which occurs at the plasma membrane. Because of lack of a specific antibody that only recognizes vRNPs, it has been unsuccessful to trace the intracellular trafficking pathway of progeny vRNPs.

We produced an anti-NP monoclonal antibody (mAb61A5) that preferentially recognizes the NP forming RNP complex rather than free NP. We initially performed confocal microscopy using mAb61A5, and found that cytoplasmic vRNPs were present as punctate signals that were accumulated around the microtubule organizing center (MTOC) soon after the nuclear export and were distributed along microtubules later on. To visualize individual vRNPs, we introduced fluorescently labeled mAb61A5 into infected cells using protein transfection reagents and carried out live-cell imaging. The vRNP signals moved along microtubules rapidly (the average velocity of $0.7-1.5 \mu \mathrm{m} / \mathrm{s}$ ) but intermittently in both directions. These data suggest that the trafficking of progeny vRNPs from the MTOC to the plasma membrane is likely mediated by the microtubule network and motor proteins. 